\title{
Brexit Damage Limitation: Tariff-Jumping FDI and the Irish Agri-Food Sector
}

Research Article

\author{
Frank Barry ${ }^{1}$, Xiaolu Sun², Benn F. Hogan² \\ 'Trinity College Dublin, Dublin, Ireland \\ 2Trinity Business School
}

\begin{abstract}
A 'hard Brexit' would be particularly damaging to the Irish beef and dairy sectors. The UK also exports substantial amounts of these products to the EU however and the vacuum that restrictions on UK access to the EU market would create affords opportunities for Irish-based producers. The aim of the paper is to assess how these opportunities might be best exploited. The results of a revealed comparative advantage (RCA) analysis conducted using international trade data do not prove encouraging. RCA analysis however implicitly treats the stock of foreign direct investment (FDI) as given. Newspaper reports are drawn upon to detail the extent of precautionary 'tariff jumping' FDI already undertaken by Irish agri-businesses. These flows thus far have been almost entirely one-way. Flows in international financial services have been in the opposite direction. These asymmetries suggest that targeted efforts by Ireland's industrial development agencies may be able to offset some of the damaging consequences of a hard Brexit.
\end{abstract}

Keywords: Brexit; agri-food sectors; foreign direct investment

(c) Sciendo

\section{INTRODUCTION 1}

Following the United Kingdom's withdrawal from the European Union at the end of January 2020, an eleven-month transition period came into effect during which existing rules on trade, travel, and business remained in operation. An agreement on future relations is to be negotiated over this period. The complexities involved in international trade negotiations notwithstanding, the UK government has announced that it will not seek an extension of the negotiating period.

In terms of the types of possible Brexits, the spectrum running from 'hard' to 'soft' refers to the height of the barriers that would be applied to UK-EU trade. The hardest of 'hard Brexits' would have arisen had the UK crashed out of the European Union without a withdrawal agreement, in which case trade would have defaulted to World Trade Organisation (WTO) rules, as explained below. The eventual signing of a withdrawal agreement, after much delay, allowed the transition period to come into effect. The term 'hard Brexit' was also used generically to refer to the UK choosing to leave both the Single Market and the EU Customs Union. The UK's rejection of free movement of labour rules out membership of the Single Market, while its stated desire to negotiate free trade deals of its own with non-EU countries is inconsistent with membership of a customs union (which is defined by its common external tariff): hence a hard rather than a soft Brexit seems to be the guaranteed outcome at this juncture.

Unless a substantive free trade deal can be negotiated between the UK and the EU then trade between them will default to WTO rules. A key WTO rule is the 'most favoured nation' clause: in the absence of a substantive free trade deal, WTO members are required to charge each other the same tariffs they apply to other WTO member states. As trade in agriculture and food is subject to particularly high WTO tariff rates ${ }^{2}$ - and tends also to be subject to burdensome non-tariff barriers - UK agri-food businesses are likely to face diminished access to the EU market. ${ }^{3}$ Even if the UK chose to slash trade barriers to EU27 firms, it would, in this scenario, have to offer this same access 
to other WTO member states, so Ireland and the rest of the EU27 would even in this case face much harsher competition on the UK market. ${ }^{4}$

Though the policy implications are of broader general applicability, as will become clear later, the main focus of the present paper is on beef and dairy. Table 1 shows Ireland's export destinations for these sectors. The UK takes around half of Irish beef exports. For the narrowly-defined dairy sector - which comprises milk, milk powders, whey, butter and cheese - the UK accounts for around 40 per cent of Irish exports. When the sector is defined more broadly to include infant formula and caseinates the proportion is closer to 20 per cent. ${ }^{5}$

Table 1: Destinations of Irish Beef and Dairy Exports, € million, 2016

\begin{tabular}{|c|c|c|c|c|}
\hline & $\mathbf{I}$ & II & III & IV \\
\hline & Exports to UK & $\begin{array}{l}\text { Intra-EU28 exports } \\
\text { (including UK) }\end{array}$ & Extra-EU28 exports & $\begin{array}{l}\text { Total exports (Columns } \\
\qquad \text { II + III) }\end{array}$ \\
\hline Irish Beef Exports & 983 & 1,897 & 142 & 2,040 \\
\hline Irish Dairy Exports (6-digit) & 680 & 1,312 & 455 & 1,768 \\
\hline Irish Dairy Exports (8-digit) & 859 & 2,037 & 1,954 & 3,991 \\
\hline
\end{tabular}

Source: Eurostat, EU trade since 1988 by HS2, 4, 7 and CN8.

The range of possible consequences of Brexit for Ireland extend well beyond the agriculture and agri-business sectors and are surveyed in ESRI (2015) and Copenhagen Economics (2018). Reflecting the high degree of uncertainty as to the future trading regime, these and the numerous studies conducted at the broader European level work through a range of scenarios based on differing combinations of tariff and non-tariff barriers. The present paper adopts, purely as a thought experiment, the most extreme of scenarios, which brings the issues of particular interest to us most clearly to the fore. This 'doomsday scenario' posits a complete cessation of UK-EU trade in beef and dairy products. Irish products lose access to the UK market but a vacuum is created in the markets of the EU27 by the prohibition on imports from the UK. How might this vacuum be filled, and specifically what share might be capturable by Ireland?

The answer will depend, on the demand side, on the degree of substitutability between the products of the individual EU27 member states and those of the UK, and, on the supply side, on available capacity and on the match between EU member state resources and the resource requirements of the particular products under consideration. ${ }^{6}$ This latter element is addressed here via the conventional shortcut method of revealed comparative advantage (Balassa, 1965). ${ }^{7}$

Revealed comparative advantage (RCA) is a measure of the relative advantage or disadvantage a particular country has in a particular sector, as evidenced by existing trade flows. ${ }^{8}$ RCA indicators for Ireland and a range of other countries have been calculated by the Department of Finance as part of its ongoing Brexit-related work, but the indices reported in Department of Finance (2017) are calculated at too high a level of aggregation for present purposes. They are calculated here at a much more disaggregated level.

The answers provided by our RCA analysis are found to offer little comfort to Irish farmers. This is where the second key element of the paper comes in. It has been noted from an earlier era of structural transformation in Ireland that RCA served as a poor predictor of future developments because of the substantial sectoral foreign direct investment (FDI) inflows that occurred as part of the process (Barry and Hannan, 2001). The reason for this is clear: RCA analysis is based on a country's existing factor endowments, and factor endowments change as a result of FDI inflows.

The FDI flows of relevance in the present case are of the 'tariff jumping' variety. ${ }^{9}$ Drawing on the parallels between Brexit-related investments by Irish agri-business firms in the United Kingdom and London-based financial firms' Brexit-related investments in Ireland, a means by which some of the potential damage of a hard Brexit might be alleviated is identified.

The issues we address are of considerable importance. The UK investments of Irish agri-food firms, though they make business sense, provide no insurance to Irish farmers. Irish agriculture will have to find new markets: given the scale of the adjustments required, this may take a considerable number of years. A second consideration is political. The positive effects of the expansion in international financial services will accrue largely to Dublin. The 
adverse shock will be much more substantial - agri-business industries and the agricultural jobs they support dwarf international financial services employment by a factor of five or six - and will impact primarily on rural regions. Such geographically-divergent outcomes have been a factor in the anti-globalisation backlash seen across much of the developed world over recent years.

The paper is structured as follows. The next section provides a review of the literature on tariff jumping FDI, comprising both the academic literature and more recent newspaper coverage of Brexit-related FDI flows. Sections 3 and 4 present the RCA analyses of the beef and dairy sectors respectively, while Section 5 returns to the issue of tariff jumping FDI to discuss the policy implications of the analysis. The paper closes with some brief concluding comments.

\section{TARIFF JUMPING FDI: LITERATURE REVIEW}

From the foundation of the Irish state until the policy shift towards export orientation in the mid-1950s most inward FDI was 'tariff jumping' in nature (Barry et al., 2016; Sweeney, 1973). Such FDI flows are frequently two-way in nature, the significance of which will become clearer later. The erection of a customs frontier on the island of Ireland in 1923, for example, induced a number of British tobacco companies to establish production facilities in Dublin, while Dundalk tobacco firm P. J. Carroll \& Co. jumped the trade barrier in the opposite direction, establishing a factory in Liverpool in 1923 to protect its British sales (Irish Times, 19 Aug. 1930).

The domestic market is of little significance for most of the well-known foreign MNCs that Ireland hosts today. For the likes of Google, Apple, Intel and Pfizer, Ireland serves as an 'export platform' from which to produce for the international market. In thinking about the implications for Brexit however it is important to recognise that the distinction between 'tariff jumping' and 'export platform' FDI is not as clear-cut as might be supposed. Though the UK in the 1920s imposed tariffs on imported cars, the fact that preferential tariff rates applied to production in Commonwealth countries caused US car manufacturers to cross the border from Detroit and establish exportplatform factories in Southern Ontario from which to 'tariff jump' into the protected UK market (Kindleberger, 1990, 141). A similar blend of FDI types was apparent in pre-EEC Ireland when one of the attractions that the Industrial Development Authority (IDA) advertised to foreign investors was the preferential access to UK and Commonwealth markets that an Irish location offered (Barry and O'Mahony, 2017).

This same blend of motivations is apparent in the case of the London-based financial services firms that have been establishing in Ireland since the 2016 UK referendum to allow them to retain access to the European Single Market. ${ }^{10}$ A report from London-based New Financial (2019) notes that assets under management amounting to hundreds of billions of pounds sterling have been moved from London to other EU locations and that Dublin has emerged as the favoured destination, ahead of rivals such as Luxembourg, Paris, Frankfurt and Amsterdam. IDAIreland (2019) recorded 55 Brexit-related investments by the beginning of 2019, with over 4,500 related jobs. The shift from London furthermore was believed at the time to have yet to begin in earnest (New Financial, 2019).

Ireland's largest agri-food businesses already had substantial operations in the UK before Brexit appeared on the radar, and this geographic diversification affords them a degree of protection against the possibility of a hard Brexit. In the case of Kerry Group, for example, more than 90 percent of its UK sales are already manufactured at its more than one dozen UK plants (Irish Times, 11 Aug 2017). In a mirror image of developments in financial services, other Irish dairy and beef firms have been working to ensure that they have adequate facilities within the UK to service that market in the event of trade barriers being erected.

Lakeland and Glanbia are among the largest Irish dairy firms, while many smaller co-operatives use Ornua, the former Irish Dairy Board, to market and sell their produce. Lakeland's purchase of Northern Ireland company Fane Valley's milk business in May 2016 was reported to provide the company with a "massive safety net" against Brexit (Irish Independent, 4 May 2017). Lakeland then went on to acquire another Northern Ireland firm LacPatrick Dairies which also had processing facilities on both sides of the border (Irish Times, 6 Mar 2019). The company's expanded cross-border presence, it was suggested, would "ensure that it avoids the worst of any Brexit fallout" (Irish Times, 7 Dec 2018).

Glanbia, though it has only a low exposure to the UK market, has contract manufacturing arrangements in place in that jurisdiction in case imports from the EU are disrupted (Irish Times, 24 Jan 2019). The company, which is described as "Europe's biggest manufacturer of mozzarella", has begun construction of a mozzarella-processing plant in Ireland to ensure EU access if exports from its current facilities in Wales and Northern Ireland are disrupted (Irish Times, 7 Dec 2018). Ornua acquired a British cheese plant in 2017 and has indicated that it has contingency 
plans to use British cheddar to supply the UK market in the event of trade disruption (Irish Times, 25 Jan 2017; Irish Independent, 25 Feb 2019).

Similar developments are apparent in the beef processing sector. Two of the largest Irish beef processors are Dawn Meats and ABP. Dawn Meats agreed a strategic partnership with Northern Ireland firm Dunbia in 2017. The latter's two large Northern Ireland plants along with its seven in Britain were described in newspaper reports as providing the Irish firm with a 'Brexit buffer' (Irish Times, 24 May 2017). Its rival, ABP, already employed 6,000 in the UK by 2017 and has been investing further since then. Its UK arm has been described as being firmly positioned "as a supplier of British beef and lamb to British retailers" (Irish Independent, 5 Jun 2018).

Why, in this case, do British agri-food businesses appear to have been slower to insure themselves against the prospect of a loss of EU market access? A recent report by Breinlich et al. (2019) finds that though the Brexit referendum vote has led to a 12 percent increase in new investments by UK firms across the rest of the EU, these investments have been confined to services sectors. The authors suggest by way of explanation that the UK government has been perceived to have prioritised the interests of manufacturers in its negotiations with the EU. Membership of the Single Market, which is of particular importance to services firms, was ruled out from the beginning: the focus was instead on minimising customs frictions. There can be no guarantee that this will continue to be the case, particularly in the case of agri-food trade given the possibility of regulatory divergence between the UK and the EU.

The logic of the processes outlined above - Irish agri-food firms 'tariff jumping' into the UK and London-based financial services firms 'non-tariff barrier jumping' into Ireland - suggests a way by which Ireland might be able to avoid some of the damage that a hard Brexit would entail. The type of FDI focused upon here has been largely overlooked in the studies conducted for the Irish government by the Economic and Social Research Institute and consultancy firm Copenhagen Economics. In discussing the FDI implications of Brexit, ESRI (2015) concentrates on the possibility of 'FDI diversion' whereby inflows that would otherwise have gone to the UK are diverted to Ireland. This is an entirely different focus from that of the present paper. The ESRI study, furthermore, is based on analysis 'of patterns of the location choice of new FDI projects in Europe over the past ten years', a methodology that cannot be used to explore the issue of interest to us. Copenhagen Economics (2018) makes only a passing reference to tariff jumping FDI, noting merely that "increasing costs of final goods trade to the EU can [make] it more attractive for the UK to use Ireland as an export hub for EU destinations".

\section{RCA ANALYSIS OF THE BEEF INDUSTRY}

Consider, purely as a thought experiment, that Brexit brings all UK-EU trade in beef and dairy products to a halt. Table 2 shows the trading position in beef and dairy (broadly defined) as of 2016, where the figures have been scaled down for ease of exposition. Ireland exports more beef to the UK than the UK exports to the rest of the EU (including Ireland). Even were Ireland to capture the entire EU market share vacated by the UK, Irish beef would remain in massive oversupply.

Table 2: Trading Position as of 2016

\begin{tabular}{ccc}
\hline & Irish exports to UK & UK exports to EU \\
\hline \hline Beef & 100 & 45 \\
Dairy (8-digit level) & 87 & 128 \\
\hline
\end{tabular}

Note: $100=€ 983$ million. Source: Eurostat, EU trade since 1988 by HS2, 4, 6 and CN8

There may be some slight comfort to be had in the fact that Ireland and the UK export to the same third-country markets, that they export the same main product category (though there are quality differences in the beef exported to the various national markets), and that Ireland has a strong revealed comparative advantage in this main export product category.

As Table 3 shows, Ireland and the UK are each other's most important destinations for beef exports, followed in descending order by the Netherlands, France, Italy and Germany. Together these markets account for 85 percent of Irish and 83 percent of total UK beef exports. ${ }^{11}$ 
Table 3: Main beef export destinations in the EU28, 2016

\begin{tabular}{ccc}
\hline & Irish exports & UK exports \\
\hline \hline UK & $52 \%$ & $30 \%$ \\
Ireland & & $24 \%$ \\
Netherlands & $10 \%$ & $15 \%$ \\
France & $8 \%$ & $8 \%$ \\
Italy & $8 \%$ & $6 \%$ \\
Germany & $7 \%$ & $83 \%$ \\
\hline
\end{tabular}

Source: Eurostat, EU trade since 1988 by HS2, 4, 6 and CN8.

As measured by international trade code categories, Ireland and the UK export similar beef products. In fact, as seen in Figure 1, the vast bulk of Irish and UK beef exports are in the same product category, i.e. HS code 020130. (The definitions of the various categories are provided in Appendix 1).

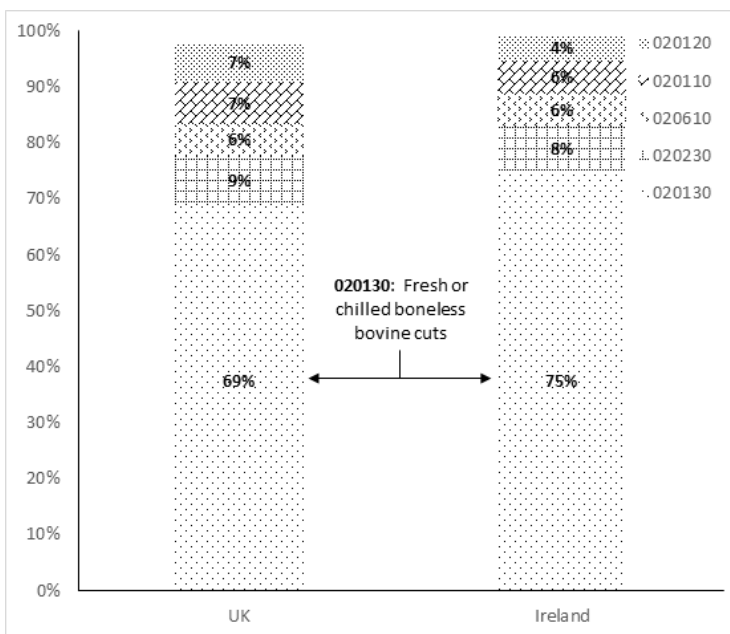

Figure 1: Intra-EU trade: beef export breakdown by main products in 2016. Note: Beef products are divided into 11 different categories at the 6-digit HS code level. The five categories shown account for 98 per cent and 99 per cent of total UK and Irish beef exports respectively. Source: Eurostat, EU trade since 1988 by HS2,4,6 and CN8.

The export price data for this category suggest however that the two countries export different cuts of meat to the various national markets. Table 4 for example shows that while Ireland receives better prices than the UK on average across the EU28, it receives lower prices in France. This is presumably a reflection of the 'carcass balance' complications referred to earlier. ${ }^{12}$

Table 4: Irish export price of beef products of trade category HS 020130 as percentage of UK export price

\begin{tabular}{|c|c|c|c|c|c|}
\hline Market & 2012 & 2013 & 2014 & 2015 & 2016 \\
\hline Netherlands & 95 & 110 & 93 & 115 & 103 \\
\hline France & 77 & 82 & 70 & 73 & 78 \\
\hline Italy & 114 & 111 & 109 & 111 & 120 \\
\hline Germany & 132 & 121 & 135 & 128 & 138 \\
\hline EU28 & 107 & 100 & 103 & 114 & 113 \\
\hline
\end{tabular}

Note: Price $=$ Total value / Total volume. Source: Eurostat, EU trade since 1988 by HS2, 4, 6 and CN8. 
Table 5 shows that Ireland has a stronger revealed comparative advantage in this export category than its principal competitors, the UK and the Netherlands. ${ }^{13}$ This suggests that Ireland should be well positioned to capture a significant share of the market vacated by the UK under the scenario considered. As is evident from Table 2 , however, even if Ireland were to capture the entirety of this newly available market Irish beef would still be left in substantial excess supply.

Table 5: Revealed Comparative Advantage in the EU market for Beef products of trade category HS 020130, 2016

\begin{tabular}{cc}
\hline Ireland & $\mathbf{1 4 . 0 6}$ \\
\hline \hline UK & 1.01 \\
Netherlands & 2.56 \\
France & 0.33 \\
Germany & 0.44 \\
Italy & 0.52 \\
\hline
\end{tabular}

Source: Eurostat, EU trade since 1988 by HS2, 4, 6 and CN8.

\section{RCA ANALYSIS OF THE DAIRY INDUSTRY}

We now conduct a similar analysis for the dairy sector, where we largely concentrate on the broad (8-digit) definition employed by the Irish agri-food industry and the Department of Agriculture, Food and the Marine. The infant formula and caseinates included in the broader definition of the sector have experienced substantial growth in recent years and - as is apparent from Table 1 - are exported largely beyond the EU. Their inclusion yields a more optimistic assessment as to the post-Brexit prospects for the sector. There is another reason too why, at first glance, the situation in dairy might appear more benign than that facing the beef industry. Table 6 shows that the vacuum created by the exclusion of UK dairy exports from the EU market would exceed the loss in Irish dairy exports to the UK. (This may be seen more clearly in Table 2 above).

Table 6: Dairy export breakdown by destinations at CN8 level, 2016 (€ million)

\begin{tabular}{ccccccc}
\hline Source & UK & Ireland & Rest of EU & Intra EU & Extra EU & Total \\
\hline \hline Ireland & $€ 859$ & & $€ 1,178$ & $€ 2,037$ & $€ 1,954$ & $€ 3,991$ \\
UK & & $€ 533$ & $€ 722$ & $€ 1,255$ & $€ 564$ & $€ 1,818$ \\
\hline
\end{tabular}

Note: These data conform to those reported in the Department of Agriculture, Food and the Marine Annual Review and Outlook, 2018. Source: Eurostat, EU trade since 1988 by HS2, 4, 6 and CN8.

It is inconceivable of course that the Irish dairy industry could capture the entirety of this newly available market. The situation is even more challenging however, firstly because - while Ireland and the UK largely export to the same group of EU countries (not shown) - they export very different dairy products (unlike in the case of beef), and secondly (and again unlike in the case of beef) Ireland does not have a comparative advantage in segments that account for the bulk of the UK's dairy exports.

Recall that in the case of beef, as seen in Figure 1, Irish and UK intra-EU exports are strongly concentrated in the same 6-digit product category, and both Ireland and the UK have a comparative advantage in this category. While there is some overlap in the case of dairy, Ireland does not have a comparative advantage in two of the top three UK 6-digit dairy export categories (Table 7), indicating that Ireland would face strong competition in attempting to fill the vacuum in these segments. Capacity matters as well as comparative advantage however, so competition would come particularly from countries with sizeable dairy herds as well as a high RCA. 
While several small EU27 states may have a strong revealed comparative advantage in some of these segments, their dairy herds would not be large enough to capture much of the market vacated by the UK. Accordingly, Table 7 focuses only on countries with significant dairy herds. ${ }^{14}$ In the case of the UK's top export category, Denmark appears to be better positioned than Ireland to fill the market vacuum that arises in our scenario. ${ }^{15}$

Table 7: Top three UK intra-EU dairy export categories (at 6-digit level)

\begin{tabular}{|c|c|c|c|}
\hline & $\begin{array}{c}\% \text { of UK intra-EU dairy } \\
\text { exports }\end{array}$ & Irish RCA & $\begin{array}{l}\text { Dominant RCA countries with } \\
\text { sizeable dairy herds among the } \\
\text { EU27 }\end{array}$ \\
\hline 040690 & 21 & 2.32 & Denmark (2.92); Ireland (2.32) \\
\hline 040120 & 16 & 0.27 & Austria (2.51); Denmark (2.51) \\
\hline 040610 & 14 & 0.57 & $\begin{array}{l}\text { Denmark (6.42); } \\
\quad \text { Italy }(2.15)\end{array}$ \\
\hline
\end{tabular}

Source: Eurostat, EU trade since 1988 by HS2, 5, 6 and CN8; Eurostat, Number of Dairy Cows - annual data, 2019.

The degree of dissimilarity between the exports of the UK and Ireland is apparent also when we move to the 8-digit product level. Though Ireland has a comparative advantage in a number of the UK's main export sub-sectors at this level, these add up to only a fraction of total UK intra-EU dairy exports (Table 8).

Table 8: UK main dairy export products in the intra-EU market and measures of Revealed Comparative Advantage for UK and Ireland in 2016

\begin{tabular}{ccccc}
\hline $\begin{array}{c}\text { UK's main export } \\
\text { products (8-digit level) }\end{array}$ & $\begin{array}{c}\text { Intra-EU UK dairy } \\
\text { exports (€ million) }\end{array}$ & Share of UK exports & UK's RCA & Ireland's RCA \\
\hline \hline 04069021 & 184 & $15 \%$ & 4.26 & 21.80 \\
04012099 & 138 & $11 \%$ & 1.44 & 0.05 \\
04061080 & 102 & $8 \%$ & 3.54 & 1.14 \\
21050010 & 88 & $7 \%$ & 0.91 & 0.10 \\
04051019 & 79 & $6 \%$ & 0.57 & 10.19 \\
19019099 & 53 & $4 \%$ & & \\
Sub-total & 643 & $51 \%$ & & \\
\hline
\end{tabular}

Source: Eurostat, EU trade since 1988 by HS2, 5, 6 and CN8.

\section{POLICY IMPLICATIONS: BREXIT DAMAGE LIMITATION}

The revealed comparative advantage (RCA) analysis does not offer great hope for Ireland's prospects of filling the dairy vacuum created by a presumptive UK exclusion from the EU market. Adjusting to Brexit will of course require Irish agri-food firms to diversify away from the UK market. Opening up new foreign markets is no easy task however. The issue explored here is whether there are grounds for believing that the adjustment can be eased, or the process supplemented, by seeking to attract particular types of UK-based firms to produce in Ireland for the post-Brexit EU market, i.e. by seeking to stimulate the mix of tariff-jumping and export-platform FDI discussed earlier in the paper. 
The more sophisticated segments of the dairy sector differ from beef in being characterised by 'marketing intangibles', of which brand names are the most visible form; others include strong customer relationships and established distribution channels (OECD, 2010). Sectors characterised by such proprietary knowledge, which also includes R\&D-related 'trade intangibles', tend to be dominated by MNC incumbents which are difficult to displace (Markusen, 1998). ${ }^{16}$ The dairy sector fits into this category in a way that beef does not, as illustrated in Appendix 3.

If customer bases have a strong attachment to incumbent dairy firms then it makes sense for Ireland to leverage its considerable experience in FDI attraction to seek to induce these UK-based firms to establish operations in Ireland. The raw materials they use are precisely those that Ireland would have in excess supply in the doomsday scenario under consideration.

There are numerous historical episodes which can be drawn upon to illustrate the use of Irish dairy raw materials by locally-based 'intangible capital'-endowed foreign firms. Fox and Breathnach's (2014) history of the mechanised creamery system in the early 20th century reveals a strong initial presence of British firms before their displacement by the burgeoning co-operatives. In most cases, as they note, these firms had been sourcing butter from Ireland in the pre-creamery era and established their own creameries to copper-fasten supply to their well-established distribution channels.

Several decades later, Rowntree and Cadbury, which had been producing chocolate confectionery in Dublin since the 1920s and 1930s respectively, commenced production of the key ingredient - chocolate crumb - at Mallow and Rathmore in the 1940s when milk and sugar remained subject to post-war rationing in Britain. Chocolate crumb subsequently became a major export industry, with Ireland reported in 1962 to be the largest exporter of chocolate products by tonnage in the world (Irish Times, May 25, 1960).

Two further historical parallels bear mention. Ballyclough's emergence as the largest co-operative creamery in the country in the early 1970 s was credited to its "diversification into the best-paying product lines" (Irish Farmers Journal, 22 May 1971). This was based on the manufacturing and sales relationships it had developed with nearby foreign MNCs - Rowntree in the case of chocolate crumb, Cow \& Gate in the case of baby food, the former Manx Creameries in the case of cheese, and US company Borden in the case of high grade milk powder (Irish Farmers Journal, 22 May 1971). The final example relates to the present-day infant formula sector, which currently accounts for some 35 percent of broadly-defined dairy exports. Three of the four key players, along with Kerry Group, are foreign MNCs. Danone now owns Cow \& Gate and operates baby-nutrition sites at Macroom and Wexford. Wyeth Nutrition supplies infant and maternal nutrition products from its factory in Askeaton, Co. Limerick, and has since 2012 been part of Nestlé, while Abbott Nutrition processes milk, whey and lactose at Cootehill, Co Cavan, to produce toddler, infant and follow-on formula for distribution across the globe..$^{17}$

These historical episodes demonstrate the feasibility of attracting UK food processing firms to Ireland to service foreign markets. For smaller UK producers, we know from an earlier era that the familiarity of the Irish environment (in terms of language and legal system for example) can represent a significant advantage (Barry, 2019). More generally, while land bridge issues and the seasonality of milk production will militate against an Irish base, a 2009 change in the UK tax system - which abolished dividend taxes on foreign repatriation from many low-tax countries, including Ireland - will work in the opposite direction (Liu, 2018). The challenge, furthermore, plays to the strengths of Ireland's development agencies. The modus operandi of the IDA was described by former managing director Padraic White as first identifying the sectors that represented a good fit for the country and then targeting particular companies and seeking to persuade them to establish operations in Ireland (White, 2000, 272).

\section{CONCLUDING COMMENTS}

Brexit is likely to be extremely damaging to Ireland's beef and dairy sectors. While Irish beef may be well-positioned to capture a strong share of the EU markets to be vacated by UK exports, quantitatively this will be nowhere near sufficient to prevent a sharp fall in the aggregate demand for Irish beef.

The analysis is more complicated in the case of dairy. The United Kingdom exports substantially more dairy products to the EU than Ireland exports to the UK. The products exported by the two states differ however, and Ireland does not display a strong comparative advantage in many of the products exported by the UK. This suggests that it would not be in a strong position to capture the EU market share vacated by UK-based firms. To the extent that Irish dairy raw materials are substitutable for UK raw material inputs, damage from Brexit could be alleviated by seeking to attract UK and UK-based downstream dairy firms to establish export platform operations in Ireland. 
The implications of the present analysis are not confined to the dairy sector. Customer loyalty will also play a significant role in other advertising-intensive and R\&D-intensive sectors (Appendix 3), and many UK firms, faced with the prospect of diminished EU-market access, may be amenable to the attractions of an Irish location.

\section{References}

Balassa, B. (1965) "Trade Liberalisation and 'Revealed' Comparative Advantage", Manchester School of Economic and Social Studies, 33, 1, 99-123.

Barry, F. (2019) "Ireland and the changing global foreign direct investment landscape", Administration, 67, 3, 93-110.

Barry, F., L. Barry and A. Menton (2016) "Tariff-jumping foreign direct investment in protectionist era Ireland", Economic History Review, 69, 4, 12851308.

Barry, F., and A. Hannan (2001) "FDI and the Predictive Powers of Revealed Comparative Advantage Indicators", https://www.researchgate.net/ publication/228581743

Barry, F., and C. O'Mahony (2017) "Regime Change in 1950s Ireland: The New Export-Oriented Foreign Investment Strategy", Irish Economic and Social History, 44, 1, 46-65.

Breinlich, H., E. Leromain, D. Novy and T. Sampson (2019) "Voting with their Money: Brexit and Outward Investment by UK Firms", CEP Brexit Analysis No. 13, Centre for Economic Performance, London School of Economics.

Copenhagen Economics (2018) Ireland and the Impacts of Brexit, Department of Business, Enterprise and Innovation.

Daly, M. E. (1984), "An Irish-Ireland for Business? The Control of Manufactures Acts, 1932 and 1934", Irish Historical Studies, 24, 246-72.

Department of Finance (2017) UK EU Exit: Trade Exposures of the Irish Economy in a European Context.

Dhingra, S., and N. Datta (2017) How not to do trade deals, London Review of Books, 39, 18, 21 Sept.: https://www.Irb.co.uk/the-paper/v39/n18/swatidhingra/how-not-to-do-trade-deals

ESRI (2015) "Scoping the Possible Economic Implications of Brexit on Ireland", Research Series No. 48, ESRI/Department of Finance.

Ferris, T. (2017) "Implications of Brexit for Ireland's Transport Sectors", Policy Brief, Dublin: Institute of International and European Affairs.

Fox, P. F., and P. Breathnach (2014) "Proprietary Creameries in Ireland", chapter 3 in Butter in Ireland: From Earliest Times to the 21st Century, Cork: Cork Butter Museum.
IDA-Ireland (2019) IDA-Ireland 2018 Results: https:// www.idaireland.com/newsroom/ida-ireland-2018results-highest-number-ever-emp

Irish Farmers Journal (22 May 1971) "Obituary: Pat Power".

Irish Farmers Journal (15 Feb 2017) "ABP gets its beef factories Brexit-ready in Britain".

Irish Independent (4 May 2017) "North milk deal delivers Brexit safety net".

Irish Independent (5 Jun 2018) "ABP will invest $£ 17 \mathrm{~m}$ in Scottish meat plant".

Irish Independent (25 Feb 2019) "Ornua prepares for Irish cheese to be locked out of the UK".

Irish Times (19 Aug. 1930) "Tobacco industry in Free State: seventeen factories now in operation".

Irish Times (25 May 1960) "Fry-Cadbury's large contribution to Irish exports".

Irish Times (25 Jan 2017) "Ornua buys UK cheese firm to bolster post-Brexit business".

Irish Times (24 May 2017) "Dawn and Dunbia announce UK joint venture ahead of Brexit".

Irish Times (11 Aug 2017) "Kerry Group trims earnings forecast".

Irish Times (7 Dec 2018) "Brexit is looming and time is running out for Irish businesses: clever companies putting in place contingency plans to deal with the many threats".

Irish Times (24 Jan 2019) "Glanbia stockpiling food in Britain to deal with a no-deal Brexit".

Irish Times (6 Mar 2019) "Lakeland's takeover of LacPatrick approved by regulatory authorities".

Kindleberger, C. (1990) Historical Economics: Art or Science?, Berkeley: University of California Press.

Lawless, M., and E. Morgenroth (2019) The product and sector level impact of a hard

Brexit across the EU, Contemporary Social Science, 14:2, 189-207.

Liu, L. (2018) "Where does Multinational Investment Go with Territorial Taxation? Evidence from the UK", IMF working paper 18/7, Washington, D.C.: International Monetary Fund

Markusen, J. R. (1998), 'Multinational Firms, Location and Trade', World Economy, 21, 6, 733-56.

Markusen, J. R. (2008) "Foreign Direct Investment", in K. A. Reinert and R. S. Rajan (eds.), The Princeton Encyclopedia of the World Economy, Princeton: 
Princeton University Press.

New Financial (2019) The New Financial Brexitometer: Analysis of how the Banking \& Finance Industry has Responded to Brexit and Who is Moving What to Where", London: New Financial.

OECD (2010) Transfer Pricing Guidelines for Multinational Enterprises and Tax Administrations, Paris.
Sweeney, J. (1973) "Foreign Companies in Ireland", Studies, 62, 247/48, 273-286.

White, P. (2000) "The muscles of the Celtic tiger: The IDA's winning sectors", in R. MacSharry and P. White, The Making of the Celtic Tiger, Cork: Mercier Press. 


\section{APPENDIX 1: BEEF SECTOR CATEGORIES}

The table below compares Irish and UK beef exports within the current 28-member European Union:

Table A1 .1: UK and lrish beef exports, intra-EU28

\begin{tabular}{|c|c|c|}
\hline & \multicolumn{2}{|c|}{ Within EU } \\
\hline € million, 2016 & Ireland & UK \\
\hline Total Beef Exports & $€ 1,897$ & $€ 439$ \\
\hline 0201 Meat of bovine animals, fresh or chilled & $€ 1,616$ & $€ 364$ \\
\hline 020110 Meat of bovine animals, carcasses and half-carcasses, fresh or chilled & $\begin{array}{l}€ 111 \\
(6 \%)\end{array}$ & $\begin{array}{l}€ 33 \\
(7 \%)\end{array}$ \\
\hline $\begin{array}{l}020120 \text { Meat of bovine animals, cuts with bone in (excluding carcasses and half-carcasses), fresh or } \\
\text { chilled }\end{array}$ & $\begin{array}{l}€ 83 \\
(4 \%)\end{array}$ & $\begin{array}{l}€ 31 \\
(7 \%)\end{array}$ \\
\hline 020130 Meat of bovine animals, boneless cuts, fresh or chilled & $\begin{array}{c}€ 1,422 \\
(75 \%)\end{array}$ & $\begin{array}{l}€ 301 \\
(69 \%)\end{array}$ \\
\hline 0202 Meat of bovine animals, frozen & $€ 153$ & $€ 42$ \\
\hline 020210 Meat of bovine animals, carcasses and half-carcasses, frozen & & $€ 0.3$ \\
\hline 020220 Meat of bovine animals, cuts with bone in (excluding carcasses and half-carcasses), frozen & $€ 1$ & $€ 2$ \\
\hline 020230 Meat of bovine animals, boneless cuts, frozen & $\begin{array}{l}€ 151 \\
(8 \%)\end{array}$ & $\begin{array}{l}€ 40 \\
(9 \%)\end{array}$ \\
\hline 0206 Edible offal of bovine animals, fresh chilled or frozen & $€ 128$ & $€ 32$ \\
\hline 020610 Offal, edible; of bovine animals, fresh or chilled & $\begin{array}{l}€ 111 \\
(6 \%)\end{array}$ & $\begin{array}{l}€ 25 \\
(6 \%)\end{array}$ \\
\hline 020621 Offal, edible; of bovine animals, tongues, frozen & $€ 1$ & $€ 0.02$ \\
\hline 020622 Offal, edible; of bovine animals, livers, frozen & $€ 1$ & $€ 0.6$ \\
\hline 020629 Offal, edible; of bovine animals, (other than tongues and livers), frozen & $\begin{array}{l}€ 14 \\
(1 \%)\end{array}$ & $\begin{array}{l}€ 7 \\
(2 \%)\end{array}$ \\
\hline 021020 Meat; salted, in brine, dried or smoked, of bovine animals & $€ 0.2$ & $€ 0.5$ \\
\hline
\end{tabular}

Source: Eurostat, EU trade since 1988 by HS2, 5, 6 and CN8.

In the EU market, Ireland has a strong revealed comparative advantage in trade category 020130, which represents the main export category for both Ireland and the UK, and in which its main competitors are the UK and the Netherlands. Ireland also has a comparative advantage in the next main export category for both countries, 020230, though this accounts for a very much smaller share of each country's exports. 


\section{APPENDIX 2: DAIRY SECTOR CATEGORIES}

HS4:

0401: Milk and cream

0402: Milk powders

0405: Butter

0406: Cheese

\section{HS6:}

040120: Dairy produce; milk and cream, not concentrated, not containing added sugar or other sweetening matter, of a fat content, by weight, exceeding $1 \%$ but not exceeding $6 \%$.

040210: Dairy produce; milk and cream, concentrated or containing added sugar or other sweetening matter, in powder, granules or other solid forms, of a fat content not exceeding $1.5 \%$ (by weight).

040510: Dairy produce; derived from milk, butter.

040590: Dairy produce; fats and oils derived from milk (other than butter or dairy spreads).

040610: Dairy produce; fresh cheese (including whey cheese), not fermented, and curd.

040690: Dairy produce; cheese (not grated, powdered or processed), n.e.c. in heading no. 0406.

\section{CN8:}

04012099: Milk and cream of a fat content by weight of $>3 \%$ but $<=6 \%$, not concentrated nor containing added sugar or other sweetening matter (excl. in immediate packings of $<=2 \mathrm{I}$ ).

04021019: Milk and cream in solid forms, of a fat content by weight of $<=1,5 \%$, unsweetened, in immediate packings of $>2,5 \mathrm{~kg}$.

04051011: Natural butter of a fat content, by weight, of $>=80 \%$ but $<=85 \%$, in immediate packings of a net content of $<=1 \mathrm{~kg}$ (excl. dehydrated butter and ghee).

04051019: Natural butter of a fat content, by weight, of $>=80 \%$ but $<=85 \%$ (excl. in immediate packings of a net content of $<=1 \mathrm{~kg}$, and dehydrated butter and ghee).

04061080: Fresh cheese "unripened or uncured cheese", incl. whey cheese and curd of a fat content, by weight, of $>40 \%$.

04069021: Cheddar (excl. grated or powdered and for processing).

19011000: Food preparations for infant use, put up for retail sale, of flour, groats, meal, starch or malt extract, not containing cocoa or containing $<40 \%$ by weight of cocoa calculated on a totally defatted basis, n.e.s. and of milk, sour cream, whey, yogurt, kephir or similar goods of heading 0401 to 0404 , not containing cocoa or containing $<5 \%$ by weight of cocoa calculated on a totally defatted basis, n.e.s.

19019099: Food preparations of flour, groats, meal, starch or malt extract, not containing cocoa or containing cocoa in a proportion by weight of $<40 \%$, calculated on a totally defatted basis, and food preparations of milk, cream, butter milk, sour milk, sour cream, whey, yogurt, kephir or similar goods in heading 0401 to 0404, not containing cocoa or containing cocoa in a proportion by weight of $<5 \%$, calculated on a totally defatted basis, n.e.s. (excl. malt extract and preparations for infant food, put up for retail sale, mixes and doughs for preparation of bakers' wares and goods in subheading 1901.90.91).

21050010: Ice cream and other edible ice, whether or not containing cocoa, not containing milkfats or containing < $3 \%$ milkfats.

35011090: Casein for the manufacture of foodstuffs and fodder and other types of casein (excl. the manufacture of artificial textile fibres and other industrial uses) 


\section{APPENDIX 3: ADVERTISING-INTENSIVE AND R\&D-INTENSIVE SECTORS}

Table A3.1 divides the 100 or so NACE70 manufacturing sectors into sectors of Type 2, where proprietary or intangible assets are of significance, and sectors of Type 1, where local firms face lower barriers to entry and which are therefore less conducive to FDI. Dairy products are seen to be categorised as advertising-intensive, of Type 2A, while beef is of Type 1.

Table A3.1 is confined to manufacturing. Within the services segment of the economy, finance and business services are known to be particularly FDI-intensive. Even within manufacturing, of course, multinational firms operate in sectors other than of the Type 2 variety. Sectors in which a country has a comparative advantage can also both attract and spawn multinational firms, which can be ascribed to 'learning-by-doing' (as reflected in the accumulation of management expertise and the development of business networks and supply chains: OECD, 2010). This helps to explain why some beef processors are among Ireland's most significant indigenous MNCs.

Table A3.1: Selection of sectors of different categories

\begin{tabular}{|c|c|c|}
\hline \multicolumn{3}{|c|}{ Advertising-intensive (Type 2A) } \\
\hline Oils and fats & Dairy Products & Fruit and vegetable products \\
\hline Confectionery & Animal foods & Other foods \\
\hline Distilling & Wine and cider & Beer \\
\hline Soft drinks & Tobacco & Toys and sports \\
\hline \multicolumn{3}{|c|}{ R\&D-intensive (Type 2R) } \\
\hline Chemicals & Man-made fibres & Machine tools \\
\hline Textile machinery & Transmission equipment & Rubber \\
\hline Computers and office mach. & Insulated wires and cables & Electrical machinery \\
\hline Electrical equipment & Telecom and measuring equip. & Electric lights \\
\hline Motor vehicle parts & Railway stock & Cycles and motor cycles \\
\hline Aerospace & Measuring instruments & Medical instruments \\
\hline \multicolumn{3}{|c|}{ Both advertising-intensive and R\&D-intensive (Type 2AR) } \\
\hline Paint and ink & Pharmaceuticals & Soaps and detergents \\
\hline Tractors and agricultural machines & Radio and television & Domestic electrical appliances \\
\hline Motor vehicles & Optical instruments & Clocks and watches \\
\hline \multicolumn{3}{|c|}{ Neither advertising-intensive nor R\&D intensive (Type 1) } \\
\hline Iron and steel & Steel tubes & Non-ferrous metals \\
\hline Clay products & Cement & Concrete \\
\hline Glass & Ceramics & Metal structures \\
\hline Boilers and containers & Food and chemical machinery & Mining and construction machinery \\
\hline Shipbuilding & Meat Products & Fish products \\
\hline Bread and biscuits & Sugar & Wool \\
\hline Cotton & Flax and hemp & Knitting \\
\hline Carpets & Misc. textiles & Leather products \\
\hline Clothing & Wooden structures & Other wood products \\
\hline Paper and pulp & Printing and publishing & Plastics \\
\hline
\end{tabular}

Source: Davies and Lyons (1996), Appendix 2.

The reason for providing the level of sectoral detail shown in the table is that the policy implications of the present analysis apply much more generally than simply to the dairy sector. 


\section{Endnotes}

1 This paper originated as a keynote address by Frank Barry to the 2017 Annual Conference of the Irish Academy of Management held at Queen's University Belfast. Subsequent drafts were presented at seminars in Trinity College Dublin, the Institute of International and European Affairs and the 2019 Annual Conference of the Dublin Economics Workshop. We are grateful to participants at these presentations for helpful discussions and suggestions. 2See Figure 3 of Lawless and Morgenroth, 2019

3 'Agri-food' is a generic term that refers broadly to agricultural and fisheries output, food and beverages but may also include wood and wood products and occasionally tobacco products.

4Dhingra and Datta (2017) serves as an accessible guide to these issues.

5Internationally traded products are classified by HS (Harmonized System) codes for customs purposes. The narrow definition uses 6-digit HS codes. The broader definition includes certain 8-digit product lines representing infant formula and caseinates (or 'baby and bodybuilder' products, as they are referred to colloquially) which are included under 'Miscellaneous Edible Products \& Preparations' in the 6-digit system. The broader definition is employed by the Irish agri-food industry and the Department of Agriculture, Food and the Marine.

6This assumes no change in the level of imports accepted from outside the EU27.

7 There are a number of complications that we do not address. One is the increased cost of transporting Irish exports to the rest of the EU associated with customs delays on the UK 'land bridge' route to continental Europe (Ferris, 2017). A second is the 'carcass balance' issue, whereby different cuts of meat are sold on British and continental markets. A third is the impact of Brexit on Common Agricultural Policy funding.

8The revealed comparative advantage index compares the share of commodity i in country i's exports to this commodity's share in the exports of some aggregate group of competitor countries. An RCA index greater than 1 indicates that country $j$ has a comparative advantage in commodity $i$ relative to the aggregate group of countries.

9Tariff-jumping foreign direct investment (FDI) arises when a foreign firm locates production within the destination market in order to avoid a trade barrier. We use the term in this broad sense to include FDI undertaken to avoid non-tariff barriers (NTBS) also.

10 Note that this 'barrier jumping' conforms to our broad definition of tariff jumping FDI.

11/t is of interest to note however that neither Ireland nor the UK are the main export suppliers of beef in any of these continental markets. Germany, for example, is the main export supplier to the Netherlands, though its key product categories are different from those of the UK and Ireland.

12 The flows in premium cuts can also vary over time. Irish exports to the UK in this particular trade category achieved higher prices than UK exports to Ireland in 2012 (not shown), but the position was reversed in each of the following four years.

13Though the Netherlands has a lower RCA than Ireland in its EU trade in this category, it exports marginally more than Ireland to the EU28. 14Eurostat (2020) Number of Dairy Cows - annual data, 2019: https://ec.europa.eu/eurostat/databrowser/view/tag00014/default/table?lang=en 15Denmark's dairy herd is less than half the size of Ireland's, but there will nevertheless be some excess capacity because it too loses its share of the UK market in this scenario.

16Thus historian Mary Daly (1984), in discussing the characteristics of early FDI inflows to Ireland, recognised that these were more likely in 'large-scale consumer industries dominated by a small number of large firms who (fight) for market shares with heavy advertising expenditures and the creation of strong brand images.

17 See investor profiles at www.Enterprise-Ireland.com 